\title{
Developing a Framework Peace Education for Primary School Teachers in Indonesia
}

\author{
Sahril Buchori, Sunaryo Kartadinata, Syamsu Yusuf and Ilfiandra \\ Universitas Pendidikan Indonesia, Indonesia \\ https://orcid.org/0000-0001-7184-8576 \\ https://orcid.org/0000-0003-3767-4706 \\ https://orcid.org/0000-0002-3775-8857 \\ https://orcid.org/0000-0002-0886-8301 \\ Nurfitriany Fakhri \\ Universitas Negeri Makasar, Indonesia \\ https://orcid.org/0000-0001-5323-8125 \\ Sofwan Adiputra \\ Universitas Muhammadiyah Pringsewu, Indonesia \\ https:// orcid.org/0000-0002-5100-1236
}

\begin{abstract}
Teachers as educators should have a sense of peace within themselves so that a conducive classroom climate can be created. The purpose of this study is to build a framework for peace education in elementary schools. To develop this capacity for peace, the researcher conducted three stages of study: the first, an empirical study; the second, developing a framework; and the third, measuring its effectiveness. This research was conducted in three schools with 12 teachers as participants. The data collection technique used an instrument of teacher peace capacity in the form of a semantic differential scale to determine the level of knowledge, skills and attitudes of teachers' peace capacity. The results show that teachers do not yet have a qualified peace capacity. This framework can be applied to teachers in the form of training. The framework for developing teacher peace capacity has proven to be effective.
\end{abstract}

Keywords: framework; teacher peace capacity; peace education

\section{Introduction}

In an era of development that is so complex, various challenges in the form of personal and social problems become important to study. One of them is the problem of living in peace and harmony. It takes a peaceful atmosphere to live together in harmony. Educational institutions are places to foster the creation of 
peace; however, they can also be places that militate against peace in society. Therefore settings and conditions are needed in educational institutions that foster peace (Setiadi et al., 2017; UNESCO-APNIEVE, 2000).

Education is the means of developing students who are peaceful and harmonious. However, the situation on the ground shows a different situation. Violent behaviour by children is currently a social problem, including in schools. This is a challenge for education in Indonesia. The results of research released in 2015 by the NGO Plan International and the International Center for Research on Women (ICRW) showed that as many as $84 \%$ of children in Indonesia experienced violence in schools (Eliasa, 2017). Violence is perpetrated by students in the form of fights both at school and outside of school, brawls, bullying, shouting at other students, skipping school, and graffiti on school walls and the school environment (Chan et al., 2013; Fung et al., 2015).

Violent social behaviour results in the destruction of basic assumptions about virtue, justice and security (Janoff-Bulman, 1992). The results of research (Buchori, 2018) show that in elementary schools there is often a less peaceful atmosphere in the classroom than outside the classroom. Students and teachers still display anti-peace behaviour in the form of an inability to contain anger. Students do not care and share, are rude, mock others and generally display provocative behaviour until a fight breaks out. These forms of violent behaviour, such as fighting at school, appear among both junior and senior high-school students, while drug use and the possession of weapons are rife (Furlong \& Morrison, 2000).

The birth of the anti-violence movement is in line with the emergence of Strengthening Character Education (SCE), which is carried out by applying the values of pancasila in character education in Indonesia. This government programme is a response to the rampant violence that occurs in schools. In addition, other movements have emerged such as the Indonesian AntiDefamation Society (MAFINDO) organisation. The MAFINDO community is concerned with educating the public, especially children, teenagers and students to prevent the spread of slander, hate speech, hoaxes, radicalism, terrorism and other anti-social behaviour. This indicates that violence has become a concern in the school environment (Nurhadi \& Muchtarom, 2020).

Violent behaviour by children at school is one of the aggressive behaviours that originate from cognitive mechanisms. Children's behaviour reflects an imitation of what is seen and heard around them, thus giving rise to normative beliefs in children (Baron, 1992; Huesmann \& Guerra, 1997; Tentama, 2012).

Children get justification for their violent behaviour in response to similar behaviour because they think that the response has become a rule of the game based on experience or general agreement that it is acceptable by those around them. This includes both physical and verbal violence (Berkowitz, 1993; Buchori \& Fakhri, 2018; Henry et al., 2000; Werner \& Hill, 2010).

Violent behaviour by students can also be influenced by teachers' behaviour. The teacher becomes a model for students to behave aggressively. This behaviour can be in the form of yelling, hitting with a ruler, and giving students derogatory nicknames (Harber, 2004; Hilarski, 2004; Meyer, 2006). Good and bad 
imitated behaviour tend to be exhibited by elementary school students because they do not have the ability to choose or differentiate.

Building peace in educational institutions has been carried out by various countries, in both formal and non-formal institutions (Harber \& Sakade, 2009). Peace education programmes are conducted in primary schools in the United Kingdom (UK) (Sakade, 2008). Such a programme, the Peacemaker Project, is carried out by the West Midlands Quaker Peace Education Project (WMQPEP). This peace education programme takes the form of conflict resolution that promotes awareness of the nature of conflict and builds nonviolent conflict management skills. The roles of researchers and teachers are those of controllers and facilitators that encourage students to be able to control themselves, to keep the rules set by themselves and be responsible for their own behaviour.

One of the studies on peace education in America was conducted by Hunter (2008), a teacher at Redland's Adventist Academy, California. Hunter created a classroom environment that fosters values such as inclusive compassion, social justice, service, and active peace. These educators provide the theoretical basis for an appropriate approach and curriculum for the classroom environment. The curriculum is designed to develop students' intellectual, emotional and social aspects. Peace education is carried out by referring to the curriculum comprising four main skills that will encourage a culture of peace among students, namely empathy training, respecting diversity of training, community awareness, and conflict resolution. This concept is emphasised in extracurricular activities. Classes are designed to provide a variety of books and tools that engage students in learning about peace. Posters and student work are displayed on a bulletin board as a reminder of the values of peace they are learning.

Peace education in Finland has been integrated into global education, which has become an explicit part of the national education system (Kartadinata et al., 2015). Peace education is carried out continuously and holistically, and aims to develop the knowledge, skills, attitudes and values needed to create peace in the form of avoiding and overcoming conflicts and violence in their environment. The process involves teachers, students, parents and the community.

Peace education was also developed by UNESCO (UNESCO-APNIEVE, 2000) under the name Peace Education, Human Rights and Democracy. Peace education reconnects peace at all levels of education, develops various methods and materials used by teachers and develops teacher education to enable them to become peacemakers. The ultimate goal is developing everyone to have universal values and the type of behaviour that form the basis for the creation of a culture of peace. Peace education, human rights and democracy are included in the curriculum in its implementation involving teachers, students, parents and the community collaborating with each other. Teaching and learning methods are directed at making peace, ensuring human rights and promoting democracy, both in the form of behaviour in school and as something that needs to be learned using active learning methods, group work, discussions on morals and ethics, and individual learning.

A requirement for developing a peaceful classroom climate is a pedagogical framework in schools. This is built through research relating to developing the 
capacity of students and teachers. Building a classroom climate begins with the teacher who has an important role in educating to build student capacity. (Freire, 1998; O'Connor, 2013; Van Manen, 1991). Teachers as role models are expected to be able to become examples and peacemakers in reinforcing students' peaceful behaviour. The normative belief of students in committing violence is caused by receiving justification through imitation and reinforcement to do so (Taylor et al., 2009). Based on this, the peace capacity of teachers in the form of knowledge, skills, and attitudes of peace needs to be developed.

The United Nations (UN) officially recognises schools as institutions that cannot be separated from the prevalence of violent behaviour in them, whether perpetrated by students, teachers or staff (Benbenishty \& Astor, 2005; Dulmus \& Harber, 2009; Pinheiro, 2006; Sowers, 2004). The rampant violence that occurs in schools has prompted the government to launch the Anti-Violence Movement in Educational Environment programme. This movement is a form of prevention and control of violence in schools.

The results of interviews with teachers revealed that elementary schools were prepared to be known for a peaceful classroom climate. It is necessary to strengthen the peace capacity of teachers in the form of knowledge, skills and attitudes so that peace can be created in the classroom and at school. Teachers need to be able to become peacemakers to build a peaceful classroom climate by educating students to have good morals and mutual love for fellow students and teachers as well as by preventing violent behaviour among students.

\section{Literature Review Peace Education}

The importance of peace education was proclaimed at the 1994 International Conference on Education and endorsed by the UNESCO General Conference in 1995 (UNESCO-APNIEVE, 2000). The phenomenon of physical and psychological violence that occurs in almost all parts of the world is most concerning. Peace education is needed for children to build understanding, solidarity, compassion and tolerance among individuals or groups. Peace education is carried out by developing knowledge, values, attitudes and skills that lead to peace. It is the process and practice of developing nonviolent skills and promoting peaceful attitudes (UNESCO, 2017).

The United Nations Children's Fund (UNICEF) defines peace education as the process of promoting the knowledge, skills, attitudes and values necessary to bring about behavioural change that will enable children, youth and adults to prevent conflict and violence, both directly and indirectly, overt and structural; to resolve conflicts peacefully; and to create conditions conducive to peace, whether at intrapersonal, interpersonal, inter- group, national or international levels (Saputra, 2016).

Kartadinata et al. (2015) define peace education as a conscious and planned effort that responds to various kinds of conflicts and violence, whether on a personal, local, national or international scale. This behaviour is an effort to create a future that is peaceful and secure in a sustainable manner. 
Peace education fosters a base of knowledge, skills, attitudes and values that seek to change patterns of thought, attitudes and behaviour related to violence. Then it transforms and builds awareness and understanding, and develops personal and social concerns that enable individuals to live in peace. It aims to create conditions and systems without violence, promote justice and care for the environment and imbue other peaceful values (Castro \& Galace, 2010).

Peace education has five main postulates, namely explaining the root causes of violence; teaching alternative behaviour; and looking for different forms of violence and eliminating them. In addition, peace is a process that varies according to the context while conflict has the potential to occur everywhere. The example of peace education in the family should be carried over by parents to their children. The function of parents in the family is to teach children about peaceful behaviour as well as being a model in instilling values in order to form character in children (Saputra, 2016).

\section{Teachers' Peaceful Capacity}

Educators should have the capacity for peace to be peacemakers. This capacity is in the form of seven main competencies of critical peace that educators should possess, namely critical thinking and analysis, empathy and solidarity, building cooperation, participatory and democratic engagement, education and communication strategy, conflict transformation skills and continuous reflection practice (Bajaj, 2015).

The peaceful capacity of teachers is their ability in the form of knowledge, skills and attitudes that reflect peace. This knowledge includes the regulation of rights, protection, strengthening of student character education, effective communication skills, conflict resolution, reflective ability, empathy, respect, democracy, and fairness.

Developing professional teacher capacity can be in the form of developing teacher knowledge, skills, attitudes and competencies in teaching (Barber, 2005; Goldman \& Grimbeek, 2008; Sinkinson, 2009). Teachers are expected to be able to practise non-violent skills, promote peaceful attitudes and find ways to achieve them (UNESCO, 2017).

The teacher's peace capacity is the teacher's ability to create peace in the classroom. Creating peace is based on mutual respect for human rights, respect, tolerance, love, democracy, and acceptance of one another (Castro \& Galace, 2010; Galtung, 1996).

Peace capacity is characterised by the presence of intrapersonal peace in the form of consistency of behaviour, emotions and attitudes towards peace; peace within oneself and in all aspects of life; and having values, competencies and cognitive dispositions that tend to promote peace. Tolerance, for example, appears to be relevant to attitudes and behaviour across all domains and will tend to influence a person to be at peace with oneself, others, and other groups (Nelson, 2014). 


\section{Methods}

\section{Research Design}

The research used a research and development approach (Borg \& Gall, 2007). The design comprised a pre-experimental study of the impact of teachers' peace capacity. The research design used is one-group pretest-posttest design in which the subject is given a pretest, then given treatment in the form of a framework for developing the peace capacity of the teacher. This is followed by a posttest.

\section{Data Collection}

The instrument of teacher peace capacity was in the form of a semantic differential scale with a range of 1 to 10. This scale was developed based on indicators of the teachers' level of knowledge, skills and attitudes of peace. This instrument aimed to collect data on the peaceful capacity of teachers in primary schools.

\section{Population and Sample}

This research involved three schools in Makassar City, namely Borong State Elementary School, Borong Impres Elementary School and Farida Aryani Madrasah Ibtidaiyah Makassar. The participants involved were 12 fourth and fifth-grade teachers to determine the sample using purposive random sampling.

\section{Research Stages}

The research procedure was carried out through six stages, namely studying the concept of teacher quality, an empirical study of the profile of teacher capacity in three schools, the development of a hypothetical training structure, training testing, intervention, and finally, evaluation of the training quality.

\section{Analysis of Research Data}

For testing the effectiveness of the training, an analysis was conducted using the Wilcoxon signed-rank and Kruskal-Wallis test rank. This data analysis technique was used to be able to determine the difference in values between the pretest and posttest. The research data has a small $\mathrm{N}$ value so that in data analysis nonparametric statistics are used.

\section{Results}

The research process to determine the level of the students' classroom climate began by measuring the peaceful capacity of the teacher who interacts with students as well as the learning process in the classroom. The results of the study regarding the initial description of the peace capacity of teachers before treatment in the form of teacher peace capacity development training can be seen in Table 1.

Table 1: Initial profile of teachers' peaceful capacity

\begin{tabular}{lccccc}
\hline & Category & formula & Score & F & $\%$ \\
\hline Teachers' & Peace & Mean +1 DD $\leq X$ & $94 \leq X$ & 1 & 8.3 \\
\cline { 2 - 6 } Peaceful & Less Peace & Mean $-1 S D \leq X<$ Mean + 1SD & $69 \leq X<94$ & 9 & 75.0 \\
\cline { 2 - 6 } Capacity & Not Peace & $X<$ Mean - 1SD & $X<69$ & 2 & 16.7 \\
\hline
\end{tabular}


Most of the teachers are in the 'less peaceful' category. Only a small number are in the 'good' category. Based on these data, in general the initial description of the peaceful capacity of teachers reflects the 'inadequate' category.

The data above shows that most teachers lack the capacity for peace in building a classroom climate. The results of this study are in line with the findings of Setiadi et al. (2017) which found that the peace capacity of teachers is still low.

According to the findings of Akhmad et al. (2016), the attitudes and behaviour of teachers contribute $50 \%$ to the non-peaceful events experienced by students at school. These behaviours include giving verbal and physical punishment to students, language that is not educating or appropriate, and reacting aggressively, both verbally and physically, to the negative behaviour of students.

The initial description of the peaceful capacity of teachers is seen from three aspects, namely aspects of knowledge, skills and attitudes.

Table 2: Aspect profile of teachers' peaceful capacity

\begin{tabular}{|c|c|c|c|c|c|}
\hline Aspect & Category & Formula & Score & $\mathrm{F}$ & $\%$ \\
\hline \multirow{3}{*}{ Knowledge } & High & Mean $+1 S D \leq X$ & $38 \leq X$ & 2 & 16.7 \\
\hline & Medium & Mean $-1 S D \leq X<$ Mean $+1 S D$ & $28 \leq X<38$ & 8 & 66.7 \\
\hline & Low & $\mathrm{X}<$ Mean - 1SD & $X<28$ & 2 & 16.7 \\
\hline \multirow{3}{*}{ Skills } & High & Mean $+1 S D \leq X$ & $27 \leq X$ & 3 & 25.0 \\
\hline & Medium & Mean $-1 S D \leq X<$ Mean $+1 S D$ & $17 \leq X<27$ & 8 & 66.7 \\
\hline & Low & $\mathrm{X}<$ Mean - 1SD & $X<17$ & 1 & 8.3 \\
\hline \multirow{3}{*}{ Attitude } & High & Mean $+1 S D \leq X$ & $30 \leq X$ & 2 & 16.7 \\
\hline & Medium & Mean $-1 S D \leq X<$ Mean $+1 S D$ & $23 \leq X<30$ & 7 & 58.3 \\
\hline & Low & $\mathrm{X}<$ Mean -1 SD & $x<23$ & 3 & 25.0 \\
\hline
\end{tabular}

The level of teacher capacity seen from all aspects of peace reflects the 'least' category. Moreover, judging from the indicators, there are 12 indicators out of 14 indicators in the medium category. Therefore teachers need to be trained in all aspects of knowledge, skills and attitudes contained in the indicators.

The capacity for peace is an important quality, especially in a teacher as an educator (UNESCO, 1996; UNESCO, 2017). However, the results of the preliminary research indicate that most teachers do not have the capacity for peace within themselves.

Table 3: Results of mean and standard deviation analysis based on pre- \& posttest training

\begin{tabular}{cccccc}
\hline Training & $\mathrm{N}$ & Mean & $\begin{array}{c}\text { Std. } \\
\text { Deviation }\end{array}$ & Minimum & Maximum \\
\hline Pretest & 12 & 81.33 & 12.565 & 61 & 96 \\
Posttest & 12 & 127.92 & 3.476 & 122 & 131 \\
\hline
\end{tabular}

Table 4: Assumptions test for Wilcoxon signed-rank test

\begin{tabular}{cccc}
\hline & $\mathrm{p}$ & $\mathrm{a}$ & Conclusion \\
\hline Posttest - Pretest KKG & .002 & 0,05 & Signifikan \\
\hline
\end{tabular}


The results of the analysis showed $p=0.002<0.05$, which means that there is a significant difference in the peace capacity or ability of the teachers before and after the training. With the difference in the mean value of pretest $=81.33$ and posttest $=127.92$, it can be concluded that after being given training, there is an increase in the peace capacity of teachers.

Based on the analysis of the Wilcoxon signed-rank test, it can be seen that $p=$ $0.002<0.05$. Therefore it can be concluded that there are differences in the peace capacity of teachers after being given training when viewed in terms of each indicator, with the biggest change occurring in the peace capacity of teachers being the indicator of 'Strengthening Character Education'.

Table 5: Results of the analysis of the mean and standard deviation based on the pre$\&$ posttest aspects of teachers' peaceful capacity

\begin{tabular}{ccccccc}
\hline Aspect & $\begin{array}{c}\text { Pre E } \\
\text { Posttest }\end{array}$ & $\mathrm{N}$ & $\begin{array}{c}\text { Minimu } \\
\mathrm{m}\end{array}$ & $\begin{array}{c}\text { Maximu } \\
\mathrm{m}\end{array}$ & Mean & $\begin{array}{c}\text { Std. } \\
\text { Deviation }\end{array}$ \\
\hline Knowledge & Pretest & 12 & 25 & 40 & 33.08 & 4.757 \\
& Posttest & 12 & 53 & 59 & 56.08 & 1.730 \\
\hline Skills & Pretest & 12 & 12 & 29 & 21.92 & 5.299 \\
& Posttest & 12 & 34 & 37 & 35.83 & 1.115 \\
\hline Attitude & Pretest & 12 & 21 & 31 & 26.33 & 3.257 \\
& Posttest & 12 & 34 & 38 & 36.00 & 1.348 \\
\hline Valid N & & 12 & & & & \\
(listwise) & & & & & & \\
\hline
\end{tabular}

Table 6: Aspect assumption test using Kruskal-Wallis analysis test rank

\begin{tabular}{cccccc}
\hline Aspect & $\mathrm{N}$ & Mean Rank & $\mathrm{p}$ & $\mathrm{a}$ & Conclusion \\
\hline Knowledge & 12 & 26.67 & & & \\
Skills & 12 & 16.63 & .003 & 0.05 & Conclusion \\
Attitude & 12 & 12.21 & & & \\
\hline Total & 36 & & & & \\
\hline
\end{tabular}

Based on the Kruskal Wallis' analysis, $\mathrm{p}=0.003<0.05$. Therefore it can be concluded that there is a difference in the peace capacity of teachers after being given training when viewed from each aspect, with the biggest change occurring in the peaceful capacity of teachers in the knowledge aspect.

\section{Discussion}

After the provision of training, there was a change in the teachers' peace capacity. There is also an increase in the number of teachers who have the capacity to be included the peaceful category. The results of this study indicate that teachers as educators should develop the capacity for peace in order to have the knowledge, skills and attitudes of peace within themselves (Arifudin, 2007; Cavanagh et al., 2012; Invernizzi, 2005; Kirkwood-Tucker, 2004; Tilaar, 1999; Widayati, 2002).

The application of peaceful values should be integrated into both educational and extracurricular activities. This can be achieved by strengthening the values of peace in supporting the learning process. In extracurricular activities, reinforcing the values of peace is carried out in order to develop the potential, 
interests, talents, abilities, personality, and cooperation of students in voicing and building peace or being peacemakers.

The capacity for peace that teachers should have is an understanding of the concept of peace in the form of the concept of diversity and relationships among communities, accepting, respecting, working with people of different backgrounds, having empathy, and exhibiting tolerance (Montgomery \& McGlynn, 2009). Teachers who have the capacity for peace are better able to provide peaceful learning (Helu, 2010). Teachers who are able to teach by applying the values of peace make students feel comfortable in receiving learning. Students who feel comfortable in participating in learning tend to find it easy to internalise the learning content. Such students should excel in class and in the community (Akhyak et al., 2013).

Students who are taught with a sense of peace are inclined to have peaceful personalities and be able to apply the values of peace in every situation and behaviour. On the other hand, students who are always at the receiving end of unreasonable behaviour from their teachers and friends will be negatively affected by this, exhibiting negative behaviour in turn (Deutsch, 1993).

Students who are taught with a sense of peace will have a happy personality, attitude and positive behaviour (Deutsch, 1993). Teachers who have a peaceful attitude are happier and find life meaningful (Kyte, 2016). Peace creates comfort and security which ultimately increases psychological well-being in individuals (Cohrs et al., 2013) and economic well-being for society (Cairns \& Lewis, 2003; Swee et al., 2019). Parents' perceptions also affect students' peace of mind (Adiputra et al., 2019).

Teachers who have the capacity for peace will teach with great compassion. Students tend to be able to follow the lessons and practise what they have learned (Naway, 2019). Moreover, teachers who have the capacity for peace are more inclined to have students with a happy personality (Biggs et al., 2008; Twemlow et al., 2005), and who can more easily deal with the various trials, challenges and problems in life (Cacioppo et al., 2011; Cohrs et al., 2013; Hetherington, 2003).

\section{Conclusion}

Trends in the peace capacity of teachers in schools contributed to the findings of research on teacher peace capacity. Teachers who have knowledge of peace will be better able to be peaceful and have peace-making skills. Then the teachers' ability to implement the values of peace in learning will increase and will lead to a peaceful atmosphere or climate in the classroom.

Based on theoretical studies and the results of empirical studies, this training is effective in developing the peace capacity of teachers in the form of increasing knowledge, skills and attitudes of teachers' peace. Teachers who have a good peace capacity will create a peaceful classroom climate. 


\section{Acknowledgment}

The writers would like to express their gratitude to the Indonesian government, especially the Indonesian Directorate General of Higher Education (DIKTI), and the Indonesia Endowment Fund for Education (LPDP) for funding this research.

\section{References}

Adiputra, S., Mujiyati, \& Hendrowati, T. Y. (2019). Perceptions of inclusion education by parents of elementary school-aged children in Lampung, Indonesia. International Journal of Instruction, 12(1), 199-212. https://doi.org/10.29333/iji.2019.12113a

Akhmad, S. N., Kartadinata, S., \& Ilfiandra. (2016). Perspektif Peserta Didik tentang Kedamaian dan Resolusi Konflik di Sekolah[Learners Perspectives on Peace and Conflict Resolution in Schools]. Pedagogia: Jurnal Ilmu Pendidikan, 14(2), 343-355. https:// doi.org/10.17509/pedagogia.v14i2.3884

Akhyak, M. A., Idrus, M., \& Bakar, A. Y. (2013). Implementation of teachers' pedagogy competence to optimizing learners' development in public primary schools in Indonesia. Journal of Education and Research, 1(9), 113-122.

Arifudin, I. (2007). Urgensi Implementasi Pendidikan Multikultural di Sekolah [The Urgency of Implementation of Multicultural Education in Schools]. Jurnal Pemikiran Alternatif Pendidikan Insania, 12(2), 220-233. https://doi.org/10.24090/insania.v12i2.252

Bajaj, M. (2015). Pedagogies of resistance and critical peace education praxis. Journal of Peace Education, 12(2), 154-166. https://doi.org/10.1080/17400201.2014.991914

Barber, N. (2005). Practitioner adaptations of strengths-based practice in statutory child protection work. The Australian Institute of Family Studies Newsletter, 13, 10-15.

Baron, J. (1992). The effect of normative belief on anticipated emotions. Journal of $\begin{array}{llll}\text { Personality and Social } & \text { 320-330. }\end{array}$ https://psycnet.apa.org/doi/10.1037/0022-3514.63.2.320

Benbenishty, R., \& Astor. S. (2005). School violence in context. Oxford University Press.

Berkowitz, L. (1993). Aggression: Its causes, consequences, and control. McGraw-Hill.

Biggs, B. K., Vernberg, E. M., Twemlow, S. W., Fonagy, P., \& Dill, E. J. (2008) Teacher adherence and its relation to teacher attitudes and student outcomes in an elementary school-based violence prevention program. School Psychology Review, 37(4), 533-549. https:// doi.org/10.1080/02796015.2008.12087866

Borg, W. R., \& Gall, M. D. (2007). Educational research: An introduction (8th ed.). PearsonAllyn \& Bacon.

Buchori, S. (2018). Profil Budaya Damai Siswa Sekolah Dasar di Cilandak Jakarta Selatan [Profile of the Peaceful Culture of Elementary School Students in Cilandak, South Jakarta]. Supriatna, M., \& dan Wahidin (Eds.). Orientasi Pribadi Optimal Perspektif Bimbingan dan Konseling. UPI Press.

Buchori, S., \& Fakhri, N. (2018). Terapi Film dalam Mengembangkan Budaya Damai Siswa [Movie Therapy in Building a Culture of Peace in Students]. Prosiding. Kongres dan Konvensi Nasional Bimbingan dan Konseling ke XX. ABKIN bekerja sama dengan Universitas Riau. Pekanbaru [Proceedings. XXth National Congress and Convention on Guidance and Counseling. ABKIN cooperates with the University of Riau. Pekanbaru].

Cacioppo, J. T., Reis, H. T., \& Zautra, A. K. (2011). Social Resilience: The Value of Social Fitness with an Application to the Military. American Psychologist, 66, 43-51. https://psycnet.apa.org/doi /10.1037/a0021419

Cairns, E., \& Lewis, C. A. (2003). Empowering peace. The Psychologist, 16, 142-143. 
Castro, L. N., \& Galace, J. N. (2010). Peace education: A pathway to a culture of peace. Center for Peace Education, Miriam College.

Cavanagh, T., Macfarlane, A., Glynn, T., \& Macfarlane, S. (2012). Creating peaceful and effective schools through a culture of care. Discourse: Studies in the Cultural Politics of Education, 343(3), 455. https:// doi.org/10.1080/01596306.2012.681902

Chan, J. Y., Fung, A. L., \& Gerstein, L. H. (2013). Correlates of pure and co-occurring proactive and reactive aggressors in Hong Kong. Psychology in the Schools, 50 (2), 181-192. https://doi.org/10.1002/ pits.21665

Cohrs, J. C., Christie, D. J., White, M. P., \& Das, C. (2013). Contributions of positive psychology to peace: Toward global well-being and resilience. American Psychologist, 68(7), 590-600. https:// psycnet.apa.org/doi/10.1037/a0032089

Deutsch, M. (1993). Educating for a peaceful world. American Psychologist, 48(2), 510-517.

Deutsch, M. (2015). Educating for a peaceful world. Springer briefs on pioneers in science and practice, 89-103. https://doi.org/10.1007/978-3-319-15443-5_7

Dulmus, C., \& K. Sowers. (Eds). (2004). Kids and violence: The invisible school experience. Haworth Press.

Eliasa, E. I. (2017). Budaya Damai Mahasiswa di Yogyakarta. Journal of Multicultural Studies in Guidance and Counseling, 1(2), 175-19. https://doi.org/10.17509/jomsign.v1i2.8286

Freire, P. (1998). Pedagogy of freedom. Ethics, democracy and civic courage. Rowman \& Littlefield Publishers.

Fung, A. L., Gerstein, L. H., Chan, Y., \& Engebretson, J. (2015). Relationship of aggression to anxiety, depression, anger, and empathy in Hong Kong. Journal of Child and Family Studies, 24(3), 821-831. http://dx.doi.org/10.1007/s10826-0139892-1

Furlong, M., \& Morrison, G. (2000). The school in school violence: Definitions and facts. Journal of Emotional and Behavioral Disorders, 8(2), 71-81. https://doi.org/10.1177\%2F106342660000800203

Galtung, J. (1996). Peace by peaceful means peace and conflict, development and civilization. Sage.

Goldman, J. D. G., \& Grimbeek, P. (2008). Student-teachers' understanding of policy behavioural directives concerning the reporting of child sexual abuse: Findings from one Australian state. Educational Research, 50(3), 291-305. https://doi.org/10.1080/ 00131880802309457

Harber, C. (2004). Schooling as violence. Routledge Falmer.

Harber, C. (2009). Forthcoming. Long time coming: Children as only occasional decisionmakers in schools. In S. Cox, S., A. Robinson-Pant, C. Dyer, \& M. Schweisfurth (Eds). Children as decision makers in education. Continuum.

Harber, C., \& Sakade, N. (2009). Schooling for violence and peace: How does peace education differ from 'normal' schooling? Journal of Peace Education, 6(2), 171187. https://doi.org/10.1080/ 17400200903086599

Helu Thaman, K. (2010). Teacher capacities for working towards peace and sustainable development. International Journal of Sustainability in Higher Education, 11(4), 353364. https://doi.org/ 10.1108/14676371011077577

Henry, D., Guerra, N., Huesmann, L. R., Tolan, P., Van Acker, R., \& Eron, L. (2000). Normative influences on aggression in urban elementary school classroom. American Journal of Community Psychology, 28(1), 59-81. 
Hetherington, E. M. (2003). Social support and the adjustment of children in divorced and remarried families. Childhood: A Global Journal of Child Research, 10, 217-236. https://doi.org/10.1177/ 0907568203010002007

Hilarski, C. (2004). Corporal punishment: Another form of school violence. In C. Dulmus and K. Sowers (Eds). Kids and violence: The invisible school experience. Haworth Press.

Huesmann, L. R., Rowell, L., \& Guerra, N. G. (1997). Children's normative belief about aggression and aggressive behavior. Journal of Personality and Social Psychology, 72(2), 408-419. https:// psycnet.apa.org/doi/ 10.1037/0022-3514.72.2.408

Hunter, T. J. (2008). Creating a culture of peace in the elementary classroom. The Education Digest, 74(1), 54-58.

Invernizzi, M. A., Landrum, T. J., Howell, J. L., \& Warley, H. P. (2005). Toward the peaceful coexistence of test developers, policymakers, and teachers in an era of accountability. The Reading Teacher, 58(7), 610618. https://doi.org/10.1598/RT.58.7.2

Janoff-Bulman, R. (1992). Shattered assumptions: Towards a new psychology of trauma. The Free Press.

Kartadinata, S., Affandi, I., Wahyudin, D., \& Ruyadi, Y. (2015). Pendidikan kedamaian. Remaja Rosdakarya.

Kirkwood-Tucker, T. F. (2004). Empowering teachers to create a more peaceful world through global education: Simulating the United Nations. Theory \& Research in Social Education, 32(1), 56-74. https://doi.org/10.1080/00933104.2004.10473243

Kyte, D. (2016). Toward a sustainable sense of self in teaching and teacher education: Sustainable happiness and well-being through mindfulness. McGill Journal of Education / Revue des Sciences de l'Education de McGill, 51(3), 1143-1162 https://doi.org/10.7202/ 1039632ar

Meyer, E. (2006). Gendered harassment in North America: Recognising homophobia and heterosexism among students. In F. Leach \& C. Mitchell (Eds.) Combating gender violence in and around schools. Trentham Books.

Montgomery, A., \& McGlynn, C. (2009). New peace, new teachers: Student teachers' perspectives of diversity and community relations in Northern Ireland. Teaching and Teacher Education, 25(3), 391-399. https://doi.org/10.1016/j.tate.2008.11.002

Naway, F. A. (2019). Sang Guru: Panduan Guru Profesional Menuju Indonesia 4.0. PGRI Gorontalo-Press.

Nelson, L. L. (2014). Peacefulness as a personality trait. In G. K. Sims, L. L. Nelson, \& M.R. Puopolo (Eds.). Personal peacefulness: Psychological perspectives. Springer.

Nurhadi, A. M., \& Muchtarom, M. (2020). Developing civic responsibility in the community through the social community "Masyarakat Anti Fitnah Indonesia (Mafindo)". In 3rd International Conference on Learning Innovation and Quality Education (ICLIQE 2019) (pp. 1087-1094). Atlantis Press.

O'Connor, P. (2013). Pedagogy of love and care: Shaken schools respond. Disaster Prevention and Management, 22(5), 425-433. https://doi.org/10.1016/j.tate.2008.11.002

Pinheiro, P. (2006). World report on violence against children. United Nations.

Sakade, N. (2008). Peace education in practice? A case study of peace education in England. (Doctoral thesis in preparation). University of Birmingham.

Saputra, W. N. A. (2016). Pendidikan kedamaian: Peluang penerapan pada pendidikan tingkat dasar di Indonesia [Peace education: Opportunities for application to primary education in Indonesia]. Jurnal CARE Edisi Khusus Temu Ilmiah, 03(3), hlm. 88-94. 
Setiadi, R., Kartadinata, S., Ilfiandra \& Nakaya, A. (2017). A peace pedagogy model for the development of peace culture in an education setting. The Open Psychology Journal, 10(1), 182-189. http:/ /dx.doi.org/10.2174/1874350101710010182

Sinkinson, M. (2009). "Sexuality isn't just about sex": Pre-service teachers' shifting constructs of sexuality education. Sex Education: Sexuality, Society and Learning, 9(4), 421-436. https://doi.org/ 10.1080/14681810903265352

Swee, E., Zhan, H., \& Powdthavee, N. (2019). Do perceptions of economic well-being predict the onset of war and peace? (No. 12650). IZA Discussion Papers.

Taylor, S. E., Peplau, L. A., \& Sears, D. O. (2009). Psikologi social: edisi dua belas [Social psychology: twelfth edition]. Kencana Prenada Media Grup.

Tentama, F. (2013). Perilaku anak agresif: Asesmen dan intervensinya [Aggressive child behavior: Assessment and intervention]. Jurnal Kesehatan Masyarakat (Journal of Public Health), 6(2), 162-232.

Tilaar, H. A. R. (1999). Beberapa Agenda Reformasi Pendidikan Nasional Dalam Perspektif Abad 21 [Several Agendas for National Education Reform in 21st Century Perspective]. Indonesia Tera.

Twemlow, S. W., Fonagy, P., \& Sacco, F. C. (2005). A developmental approach to mentalizing communities: II. The Peaceful Schools experiment. Bulletin of the Menninger Clinic, 69(4), 282-304. https://doi.org/10.1521/bumc.2005.69.4.282

UNESCO. (1996). Learning: Treasure within. UNESCO Publishing.

UNESCO. (2017). Transformative pedagogy for peace-building: A guide for teachers. UNESCOInternational Institute for Capacity Building in Africa (IICBA).

UNESCO-APNIEVE. (2000). Belajar untuk Hidup Bersama dalam Damai dan Harmoni: Pendidikan Nilai untuk Perdamaian, Hak-hak Asasi Manusia, Demokrasi dan Pembangunan Berkelanjutan untuk Kawasan Asia-Pasifik [Learning to Live Together in Peace and Harmony: Values Education for Peace, Human Rights, Democracy and Sustainable Development for the Asia-Pacific Region]. Buku Sumber UNESCO-APNIEVE untuk Pendidikan Guru dan Jenjang Pendidikan Tinggi. Penerjemah W.P. Napitupulu. Bandung: Komisi Nasional Indonesia untuk UNESCO dan UPI.

Van Manen, M. (1991). The tact of teaching: The meaning of pedagogical thoughtfulness. Althouse Press.

Werner, N. E., \& Hill, L. G. (2010). Individual and peer group normative beliefs about relational aggression. Child Development, 81(3), 826-836. https:// doi.org/10.1111/j.1467-8624.2010.01436.x

Widayati, S. (2002). Reformasi pendidikan dasar [Primary school education reform]. Grasindo. 